\title{
E-Word of Mouth in Increasing the Number of Marine Tourism Visits to the Bintan Regency, Riau Islands
}

\author{
Lia Suprihartini ${ }^{1}$ \\ \{liasuprihartini@gmail.com\} \\ ${ }^{1}$ Raja Ali Haji Maritime University
}

\begin{abstract}
The Digital Era 4.0 brings enormous changes to people's social behavior, changing how consumers get information for tourism destinations. This change has shifted Word of Mouth (WOM) into an Electronic Word of Mouth (E-WOM) in searching for, selecting-purchasing and evaluating information of desired tourism destinations more quickly. This research is qualitative descriptive research through literature study, observation, and previous studies, which aims to understand in-depth whether E-WOM can affect the level of tourist visits to the Bintan Regency, Riau Islands through a social media platform. The results indicate an increase in intensity in visiting marine tourism destinations. Many photos and videos are uploaded by domestic and foreign tourists both on social media accounts managed by tourism communities and personal accounts owned by tourists. The presence of these communities has had a significant influence on the rapid development of Bintan tourism. From WOM marketing, we can describe it in one word, trust, both positive and negative.
\end{abstract}

Keywords: E-WOM, Marine Tourism, social media.

\section{Introduction}

The Riau Islands is an archipelagic province of 2,408 islands, of which $30 \%$ are uninhabited. It has great potential for marine tourism because it consists of $95.79 \%$ ocean and $4.21 \%$ land. In Indonesia, tourism is one of the main sectors that advance economic growth. The tropical climate and the natural, artistic, and cultural wealth are vital areas for tourism in the Riau Islands. For Riau Islands, Marine tourism is a potential field that increases regional income and improves the welfare of local people. The Bawah Island in the Anambas Archipelago was included in CNN's presentation of the best tropical islands in Asia. In addition, Sisi Beach in Natuna was also named one of the best natural beaches in the world in Island magazine in 2006. Penyengat Island and Bintan Island are some examples of popular tourist destinations in the Riau Islands. ${ }^{1}$

Bintan Island is the largest island in the Riau Archipelago. The area of Bintan Regency is $88,038.54 \mathrm{Km}^{2}$, although the mainland accounts for only $2.21 \%\left(1,946.13 \mathrm{Km}^{2}\right)$. Bintan Island stretches between Singapore and Johor Bahru, Malaysia, and extends from Malacca to

\footnotetext{
${ }^{1}$ Source: https://www.indonesia.travel/gb/en/destinations/sumatra/bintan-island/ anambas-island
} 
the South China Sea.Bintan Regency currently consists of 240 large and small islands, of which is only 39 islands are inhabited. ${ }^{2}$

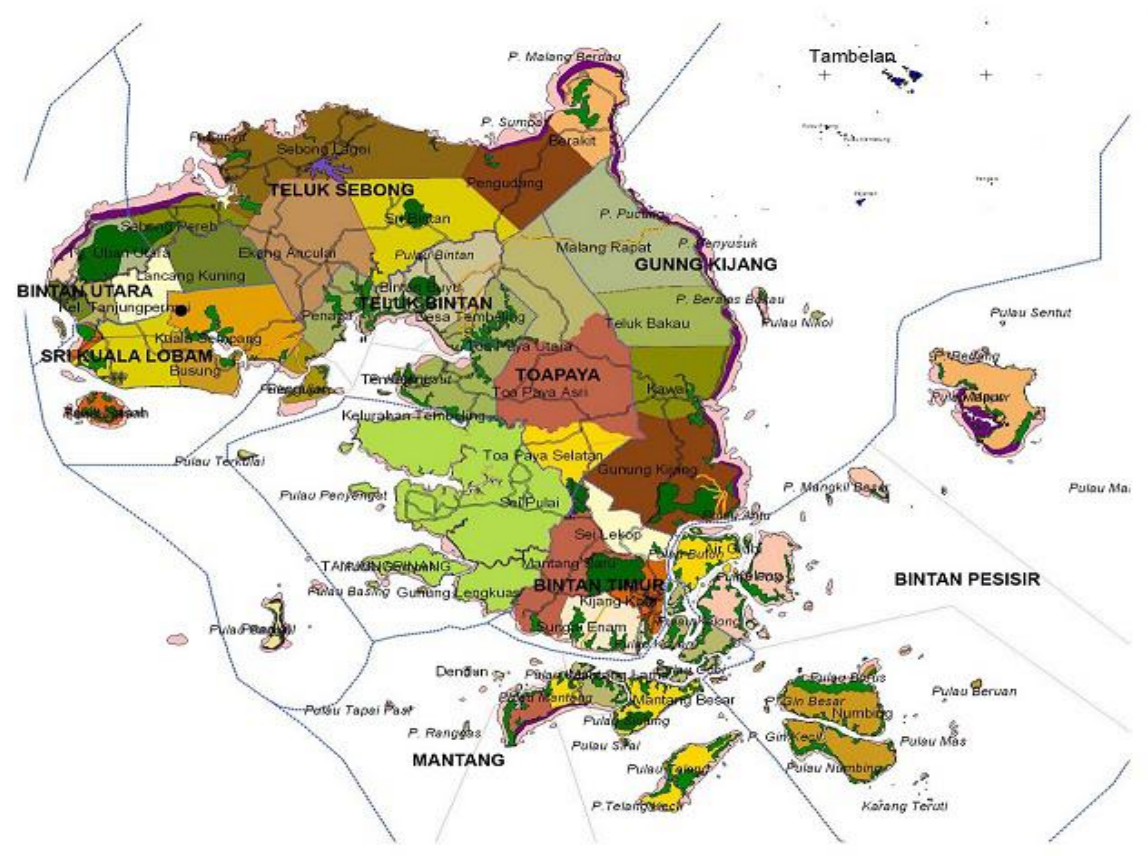

Fig. 1.Map of Bintan Regency.

The Riau Islands boasts the natural beauty of the sea and beaches, which could be developed and marketed nationally and internationally. According to BPS (Statistics Center Bureau) for Nusantara in 2018, of the total 275 million domestic tourists, $19.61 \%$ undertook Marine Tourism trips. Some of the best tourist destinations offered in the Riau Islands are in the Bintan Regency, namely, LagoiBintan Tourist Area, Trikora Beach Tour, White Sands Island, MapurNikkoi Island, and Cempedak Island.

However, BPS noted that cumulatively during January-November 2020, the number of tourist visits to Kepri decreased by 84.08 percent compared to the same period in 2019 , i. e. from 2,587,881 visits to 411,913 visits. According to the Head of Kepri BPS AgusSudibyo, "the decline is due to the outbreak of COVID-19, so the impact is certainly huge on the Kepri tourism sector." 3

In the Digital Era, people's social behavior changes in getting information about tourism destinations. Electronic Word of Mouth (E-WOM) is one of its digital media in searching for, selecting, evaluating, and purchasing the desired tourism destinations. Wang (2015), Setiawan (2014), Auliya\&Pertiwi (2019), and Hartini et al. (2020) are among others to suggest the influence of E-WOM on tourism visits growth. It is interesting then to investigate the effectiveness of a social media platform in increasing tourist visits to the Bintan Regency, Riau Islands Province.

${ }^{2}$ Source: https://en.wikipedia.org/wiki/Bintan_Regency

${ }^{3}$ Source: https://www.antaranews.com/berita/1927608/kunjungan-wisman-ke-kepriturun-9927-persen 


\section{$2 \quad$ Literature Review}

In the current era of technology 4.0, there is a shift in consumer behavior patterns in choosing, determining, and receiving information. In this digital era, humans are more efficient at finding and sorting all forms of information they receive. There has been a shift in consumer behavior patterns getting and about everything to meet their needs and desires in life in activities. In getting. With media that use or apply Internet network technology, it can quickly disseminate messages or information that it publishes to the broader community (Sima et al. 2020).

Kotler and Keller (2016) stated that selecting the right promotional media determines the segment, audience, time, cost, and effectiveness of the promotion. Blanchard (2011) said that online media and social media are popular among the global community today. The increasing use of social media can change consumer behavior in communicating, sharing ideas, providing recommendations for a product, or interacting with each other in influencing. Consumers seek information that is detailed and instant, easy, and fast. Access to information obtained through social media, supporting smartphone (mobile) technology, and digital social networks can trigger changes in patterns and ways of thinking, lifestyle, self-existence, selfpride, socio-culture, etc.

A survey conducted by APJII (Association of Indonesian Internet Service Providers) in 2018 found that Indonesia's number of internet users is $64.8 \%$ of the total population, approximately 264.16 million people. Research by Hootsuite released in January 2019 showed that social media users in Indonesia reached 150 million, or $56 \%$ of the total population. This number is up $20 \%$ from the previous survey. Meanwhile, mobile social media (gadget) users reached 130 million or around $48 \%$.

The demographic information above shows the development of social media users in Indonesia. The large population and the rapid growth of Internet and Smartphone users, making Indonesia potentials for the national digital economy. As a result, e-Commerce, online transportation, online stores, and other internet-based businesses are developing. It will be a strength of the digital economy in the Southeast Asia region. Social media users can meet their information needs in a way that is easy, cheap, and fast, including information concerning the tourism sector.

Digital media allows customers to show and share their experiences and inspire other customers from the same or maybe different social classes to imitate and have a similar experience. Netizens, as digital actors, understand how to deal with other people online while sharing information. Even if people access data that is not completely valuable productive, they are an excellent example of intelligent customers. Netizens demonstrate democratic behavior without boundaries expressing their feelings and opinions freely. They make ratings, throw comments (posts), and even create content for other digital media users. This study aims to determine whether (E-WOM) can have a strong influence on Consumer Behavior to shape the decision of tourists to visit Bintan Regency, Riau Islands, and affect the number of marine tourism visits in Bintan Regency, Riau Islands.

The main text should be written using Times New Roman, 10pt, entirely justified. Italics can be used for emphasis, and bold typeset should be avoided. 


\section{Methodology}

This article uses a qualitative method with descriptive analysis through the literature study. This study uses secondary data, such as research reports, books, and research journals that are relevant and relevant to the research. (Hardani; et al. 2020).

\section{Discussion}

In the current era of disruption, there have been significant changes in all aspects, including marketing. Marketing 4.0 describes in detail the complete approach that takes customers from realizing to encouraging. The internet, which brings connectivity and transparency to our lives, is the leading cause of this change. With an Internet system, buyers will have easy access to various sources of information. The high level of internet users will undoubtedly help implement and significantly influence promotional activities, including the Tourism Business.

Currently, the traditional buying route (aware, interested, asking, and acting) is expanded by advocating. It is because the opinions of our family and friends impact buying decisions, the way to cultivate experience. In marketing, Word of Mouth Association (WOMMA) defines Word of Mouth Marketing as a person's action in sharing exciting information with others. The image of a product or service is significantly formed through advertising and WOM. WOM recommendations from friends and relatives are essential sources to shape the reputation of a tourist destination (Pan, Rasouli, and Timmermans 2021). Consumers can obtain information through the internet, articles, brochures, books, and films (Gómez et al., 2018).

In the current digital Era, Word-of-Mouth has also shifted to Electronic Word-ofMouth (E-WOM). The need to understand E-WOM in marketing business activities is critical. Understanding E-WOM through social networks is very important because, with social networks, consumers can reach the public efficiently and quickly (Tran and Strutton, 2020). Electronic word-of-mouth can undoubtedly increase the efficiency of promotional activities. The rapid development of technology supported by the presence of Smartphones at a relatively low price allows consumers to surf the virtual world, access social media, and obtain various information they need related to tourism activities, also known as lifestyle tourism. Lifestyle tourism is an emerging concept in the marketing of tourism destinations, which insists on lifestyle aspects of leisure travel searching for new experiences (Gross 2018).

Based on the results of previous research, one in three tourists who visited forums or online tourism communities trusted the information provided before making a payment (Gustiani 2018). One way to get many loyal advocates is to raise awareness. The more people remember a brand or experience, the more likely it is to be recommended. For this reason, connectivity is needed in the customer line to increase awareness by sparking conversations between customers. In this digital era, consumer conversation has enormous leverage. Through various forms of social media, the chat, status, and the many shared photos are used as references in selecting tourist destination areas, including marine tourism destinations in Bintan Regency, Riau Islands.

Tourists who obtain information from someone's experience regarding the destination of a tourist spot will be significantly helped by simply searching through social media or the transportation service provider websites. In social media, people can choose with whom they 
want to communicate, use messaging applications, exchange messages, photos, music, videos, etc. According to research conducted by Artaya et al. (2020), tourists who have received complete information about tourist objects will be more open to trying various activities offered by the tourist objects.

In the era of 4.0, where technology is increasingly advanced, consumer behavior has also changed. There is a shift in the customer path (Consumer Path) from the pre-Connectivity era towards the customer line in the Connectivity Era. In the pre-Connectivity age, a customer determines their attitude towards the brand. However, in the Era of Connectivity, the initial attractiveness of a brand is influenced by the community where the customer is. In the preconnectivity era, loyalty is defined as retention and re-purchasing, while in the age of connectivity, loyalty is defined as the willingness to advocate a brand. The Consumer path was original '4A;' aware, attitude, act, and act again. It shifted into '5A', which stands for: knowledgeable, appeal, ask, action, and advocate (Kotler, Kartajaya, and Hooi 2019). The loyalty that occurs today is willingness and activeness to be an Advocate for a Brand. Consumers or customers are becoming increasingly careful about how they will make decisions to determine their purchases. The power of the current media, or what we know as Viral Marketing and Electronic Word of Mouth, is increasingly having an influence.

In the current industry 4.0 era, tourism business actors must also fulfill the wishes of and changes in people's behavior today regarding all tourism information. Based on research conducted by Travelport Global Digital Traveler, the country of origin of tourists who mostly use technology while on vacation, India is in the first place, followed by Indonesia in the second place. Mark Meehan, Managing Director of Travelport for the Asia Pacific, Middle East, and Africa region, said that India and Indonesia have grown, especially in smartphones. The survey was conducted on 16,000 tourists from 25 countries. The research also found that tourists actively interact with other tourists through digital platforms, instant messaging applications, and social networks. ${ }^{4}$

In April and May 2015, the Agoda.com Transportation Service Provider surveyed more than 5,500 respondents who were Agoda.com customers from all over the world. The focus was on which resource was seen as a reliable travel guide. The results found that online forums were the most popular; 34\%. The second-highest ranking was personal/independent travel blogs and sites; $28 \%$. When combined with online guidance sources, which include forums, blogs, and applications (mobile apps), they make up a total of $71 \%$ of all survey results answered by respondents. ${ }^{5}$

Tourists are currently exploring the internet and finding various sources of information they need; they can quickly access knowledge or experiences from other travelers who share their travel information via the internet. Additionally, the quality of photographs uploaded online on social networks is considered critical to promoting a tourist destination. The role of photography makes tourist destinations increasingly popular and attracts many tourists to visit. "Photos must be able to provide attraction. This capture is essential as a tool to invite tourists. According to DadangRizkiRatman, Deputy for the Development of Destinations and Tourism Industry of the Ministry of Tourism (PDIP Kemenpar), during his remarks at the Photography Workshop for Tourism Journalists in the Cooperation of the Tourism Journalists Forum and Deputy of PDIP Kemenpar, which was held at Historia Lounge \& Bar, Kota Tua Tourism Area, West Jakarta. With the emergence of various tourism communities such as the Indonesian Tourism Generation (Genpi), the benefits of their existence cannot be

\footnotetext{
${ }^{4}$ Source: https://websindo.com/indonesia-digital-2019-media-sosial/

${ }^{5}$ Source: www.agoda.com
} 
underestimated. The Indonesian Tourism Generation community introduce Indonesian tourism by sharing their exploration through their status update on social medial. ${ }^{6}$

Creating a positive image and a pleasant tourism experience is very important for tourism actors today. When a product or service has appealed tothe public's hearts, it will automatically create a positive Word of Mouth and Electronic Word of Mouth, which can undoubtedly reduce promotional costs incurred by the Company.

\section{Result}

From the previous discussion, it can be seen that there is currently high intensity of society in accessing information via the internet, especially social media, chats in the comments column on tourism information sites, and uploading photos, and videos. The status of social media, managed by several tourism communities and photography communities, and personal accounts owned by tourists, shows that the Electronic Word of Mouth has a significant influence in supporting the level of marine tourism visits in Bintan Regency Riau Islands. Furthermore, several communities, such as the tourism community and the photography community, can significantly influence the rapid development of tourism in Bintan Regency and turn Bintan into the new face of tourism in Riau Island Archipelago.

\section{References}

[1] Auliya, ZakkyFahma, and ImandaFirmantyasPutri Pertiwi. 2019. "The Influence of Electronic Word of Mouth (E-WOM) and Travel Motivation toward the Interest in Visiting Lombok, Gender as a Mediator." INFERENSI: JurnalPenelitianSosialKeagamaan 13(2):201-18. doi: 10.18326/INFSL3.V13I2.201-218.

[2] Blanchard, Olivier. 2011. Social Media ROI: Managing and Measuring Social Media Efforts in Your Organization. Pearson Education.

[3] Gómez, Mar, Brian Imhoff, David Martín-Consuegra, Arturo Molina, and María Leticia SantosVijande. 2018. "Language Tourism: The Drivers That Determine Destination Choice Intention among U.S. Students." Tourism Management Perspectives 27:125-35. doi: 10.1016/J.TMP.2018.06.001.

[4] Gross, Michael J. 2018. "Lifestyle Tourism."The Routledge Handbook of Popular Culture and Tourism464-76. DOI: 10.4324/9781315559018-40.

[5] Gustiani, Maftukhah. 2018. "Peran Electronic Word of Mouth DalamMembangun Citra DestinasiGunaMempengaruhiKeputusanBerkunjungWisatawanKeSuatuDestinasiPariwisata." Competence : Journal of Management Studies 12(2). doi: 10.21107/KOMPETENSI.V12I2.4962.

[6] Hardani;, NurHikmatul; Auliya, Helmina; Andriani, RoushandyAsri; Fardani, Jumari; Ustiawaty, EviFatmi; Utami, Dhika Juliana; Sukmana, and RiaRahmatul; Istiqomah. 2020. MetodePenelitianKualitatif\&Kuantitatif. 1st ed. edited by H. Abadi. Yogyakarta: PustakaIlmu.

[7] Hartini, Sri, DienMardhiyah, and SukarisSukaris. 2020. "Determinant of E-WOM: Popularity Destination, Value and Conspicuous Tendency Regarding Adventure Tourism." International Journal of Innovation, Creativity, and Change. Www.Ijicc.Net 11(1):539-60.

6"KualitasFotografiTentukanKeberhasilanPromosiDestinasiWisata", by WahyuAdityoProdjo

[https://travel.kompas.com/read/2017/10/06/093500527/kualitas-fotografi-

tentukan-keberhasilan-promosi-destinasi-wisata] 
[8] Kotler, Philip, HermawanKartajaya, and Den HuanHooi. 2019. Marketing 4.0: Moving From Traditional To Digital. New Jersey: Wiley.

[9] Kotler, Philip, and Kevin Lane Keller. 2016. Marketing Management. 15th ed. Pearson Education Limited.

[10] Pan, Xiaofeng, SooraRasouli, and Harry Timmermans. 2021. "Investigating Tourist Destination Choice: Effect of Destination Image from Social Network Members." Tourism Management 83:104217. DOI: 10.1016/J.TOURMAN.2020.104217.

[11] Setiawan, PutuYudi. 2014. "The Effect of E-WOM on Destination Image, Satisfaction, and Loyalty." International Journal of Business and Management Invention ISSN 3:22-29.

[12] Sima, Violeta, Ileana Georgiana Gheorghe, JonelSubić, and DumitruNancu. 2020. "Influences of the Industry 4.0 Revolution on the Human Capital Development and Consumer Behavior: A Systematic Review." Sustainability (Switzerland) 12(10). DOI: 10.3390/SU12104035.

[13] Tran, Gina A., and David Strutton. 2020. "Comparing Email and SNS Users: Investigating eServicescape, Customer Reviews, Trust, Loyalty, and E-WOM." Journal of Retailing and Consumer Services 53:101782. DOI: 10.1016/J.JRETCONSER.2019.03.009.

[14] Wang, Ping. 2015. "Exploring the Influence of Electronic Word-of-Mouth on Tourists' Visit Intention: A Dual-Process Approach." Journal of Systems and Information Technology 17(4):38195. DOI: 10.1108/JSIT-04-2015-0027. 